\title{
Detection and characterization of hydraulically active fractures in a carbonate aquifer: results from self-potential, temperature and fluid electrical conductivity logging in the Combioula hydrothermal system in the southwestern Swiss Alps
}

\author{
B. Suski • F. Ladner • L. Baron - F.-D. Vuataz • \\ F. Philippossian • K. Holliger
}

\begin{abstract}
A geophysical and geochemical study has been conducted in a fractured carbonate aquifer located at Combioula in the southwestern Swiss Alps with the objective to detect and characterize hydraulically active fractures along a 260-m-deep borehole. Hydrochemical analyses, borehole diameter, temperature and fluid electrical conductivity logging data were integrated in order to relate electrokinetic self-potential signals to groundwater flow inside the fracture network. The results show a generally good, albeit locally variable correlation of variations of the self-potential signals with variations in temperature, fluid electrical conductivity and borehole diameter. Together with the hydrochemical evidence, which was found to be critical for the interpretation of the self-potential data, these measurements not only made it possible to detect the hydraulically active fractures but also to characterize them as zones of fluid gain or fluid loss. The results complement the available information from the corresponding litholog and illustrate the potential of electrokinetic self-potential signals in conjunction with temperature, fluid electrical conductivity and hydrochemical analyses for the characterization of fractured aquifers, and thus may offer a perspective for an effective
\end{abstract}

Received: 11 October 2007 / Accepted: 13 March 2008

Published online: 17 May 2008

(C) Springer-Verlag 2008

B. Suski $\cdot$ L. Baron $\cdot$ K. Holliger $(\bullet)$

Institute of Geophysics, University of Lausanne,

Amphipole Building, 1015, Lausanne, Switzerland

e-mail: klaus.holliger@unil.ch

F. Ladner

Geothermal Explorers LTD,

Schlossstrasse 3, 4133, Pratteln, Switzerland

F.-D. Vuataz

Center for Geothermal Research, c/o CHYN,

University of Neuchâtel,

Rue Emile-Argand 11, 2009, Neuchâtel, Switzerland

F. Philippossian

Bureau d'Etudes Géologiques S.A.,

Rue de la Printse 2, 1994, Aproz, Switzerland quantitative characterization of this increasingly important class of aquifers and geothermal reservoirs.

Résumé Une étude géophysique et géochimique a été menée dans un aquifère carbonaté fracturé à Combioula dans les Alpes Suisses du Sud Ouest avec pour objectif la détection et la description des fractures actives hydrauliquement sur la longueur d'un forage profond de $260 \mathrm{~m}$. Des analyses hydrochimiques, des données de diagraphies du diamètre du forage, de la température et la conductivité électrique du fluide ont été combinées afin de relier des signaux électrocinétiques de polarisation spontanée à l'écoulement d'eau souterraine à l'intérieur du réseau de fractures. Les résultats montrent une corrélation généralement bonne, bien que localement avec une corrélation changeante des variations des signaux de polarisation spontanée avec les variations de température, de conductivité électrique du fluide et du diamètre du forage. Avec la signature hydrochimique, qui a été trouvée être cruciale pour l'interprétation des données de polarisation spontanée, ces mesures ont non seulement rendu possible la détection des fractures actives hydrauliquement mais aussi de les décrire comme zones de gain de fluide ou de perte de fluide. Les résultats complètent l'information disponible provenant des logs lithologiques correspondants et expliquent les potentialités des signaux électrocinétiques de polarisation spontanée en liaison avec la température, la conductivité électrique du fluide et les analyses hydrochimiques pour la description des aquifères fracturés et peuvent ainsi offrir une approche pour une description quantitative efficace de cette catégorie d'aquifères et de réservoirs géothermaux d'importance croissante. Détection et description de fractures actives hydrauliquement dans un aquifère carbonaté : résultats de diagraphies de polarisation spontanée, de température et de conductivité électrique du fluide dans le système hydrothermal de Combioula dans les Alpes Suisses du Sud Ouest

Resumen Estudios geofísicos y geoquímicos han sido llevados a cabo en el acuífero carbonático fracturado localizado en Combioula, sudoeste de los Alpes Suizos, a in de detectar y caracterizar fracturas hidráulicamente 
activas en una perforación de $260 \mathrm{~m}$ de profundidad. Se han integrado datos de análisis hidroquímicos, diámetro de la perforación, temperatura y conductividad eléctrica del fluido para relacionar las señales de potencial espontáneo con el flujo subterráneo en la red de fracturas. Los resultados muestran una buena correlación entre las variaciones del potencial espontáneo y las variaciones en temperatura, conductividad eléctrica del fluido y diámetro de la perforación, aunque se registran variaciones locales. La evidencia hidroquímica resultó crítica para la interpretación de los datos de potencial espontáneo, y así fue posible detectar no sólo las fracturas hidráulicamente activas sino también caracterizarlas como zonas de ganancia o pérdida de fluidos. Los resultados complementan la información disponible de los perfiles litológicos e ilustran el potencial de las señales electrocinéticas de potencial espontáneo en conjunto con la temperatura, la conductividad eléctrica del fluido y los análisis hidroquímicos para la caracterización de acuíferos fracturados, y de esta manera ofrecen una perspectiva para la caracterización cuantitativa efectiva de esta clase de acuíferos de importancia creciente y de reservorios geotérmicos. Detección y caracterización de fracturas hidráulicamente activas en un acuífero carbonático: Resultados de registros de potencial espontáneo, temperatura y conductividad eléctrica de los fluidos en el sistema hidrotermal de Combioula, sudoeste de los Alpes Suizos

Keywords Switzerland · Hydrogeophysics · Fractured rocks · Groundwater flow $\cdot$ Self-potential logging

\section{Introduction}

In mountainous regions such as the Alps, pronounced topography, complex geology and seasonally accentuated and generally precipitation-rich climatic conditions in conjunction with the inherently complex geological setting and associated prominent spatial variations in permeability largely govern the development of deepwater circulations. In particular, the generally strong hydraulic gradient, the presence of highly permeable geological formations and/or deep-reaching faults and fractures allow deep-water infiltration and circulation and thus favour the formation of medium- to high-temperature aquifer systems (e.g., Forster and Smith 1988; Lopez and Smith 1995).

In this context, fractured aquifers are of particular interest and importance. They are generally characterized by strong heterogeneity due to the inherently large contrasts in hydraulic properties between the highly permeable fractures and the surrounding rock matrix of generally negligible permeability. In addition to their geothermal potential, fractured aquifers are also increasingly used for ensuring the groundwater supply in several regions of the world (e.g., Jeong 2001; Mapani 2005; Durand et al. 2006). The sustainable use of these groundwater and geothermal resources requires a detailed knowledge of their hydraulic properties, which makes the detection and hydraulic characterization of the fractures an ever more important task (e.g., Lemieux et al. 2006). In addition to traditional hydrogeological techniques such as core analyses, flowmeter measurements as well as tracer and pumping tests, borehole geophysical measurements are becoming increasingly important (e.g., Paillet 2004; Le Borgne et al. 2006).

Although there are a number of techniques that are sensitive to the presence of fractures, most common geophysical methods do not provide any information with regard to their hydraulic activity. This problem can be potentially alleviated through self-potential measurements, which exhibit a direct sensitivity not only to movement of fluids within fractures but also to their dominant flow direction (e.g., Bogoslovsky and Ogilvy 1973; Wishart et al. 2006). A particular advantage of self-potential logs in fractured aquifers could thus be that they are directly sensitive to the generally sub-horizontal in- and outflows along fractures and that they are considered to be capable of detecting very weak fluid movements. Although the promise of self-potential measurements for the detection and characterization of hydraulically active fractures is widely acknowledged (e.g., Ogilvy et al. 1969; Sharma and Baranwal 2005; Rozycki et al. 2006), corresponding methodological studies and/or systematic practical applications for borehole measurements are few and far apart (Hunt and Worthington 2000; Ishido and Pritchett 2003).

This report presents the results of an integrated study including hydrochemical analyses and self-potential measurements, complemented by temperature, fluid electrical conductivity and borehole diameter, or caliper, logs, along a 260-m-deep borehole. The site for this study is located within the Combioula hydrothermal system in the southwestern Swiss Alps, which in many ways can be regarded as being typical of a fractured geothermal aquifer in a mountainous region (Vuataz 1983). A particular objective of this study is to explore the fundamental applicability and practical usefulness of self-potential borehole measurements in such environments for detecting and characterizing hydraulically active fractures.

\section{The Combioula geothermal site}

The Combioula hydrothermal system is located at $693 \mathrm{~m}$ above sea level at the beginning of Val d'Hérens, a deep glacial valley in the so-called Penninic region in the southwestern Swiss Alps. Detailed descriptions of the regional geology are given by Escher (1988), Sartori and Marthaler (1994), and Steck et al. (2001). The region is characterized by a strong topography with steep slopes and a high average elevation ranging between 2,500 and $3,000 \mathrm{~m}$ above sea level. From a hydrogeological point of view, this Penninic region can be regarded as a complex superposition of multiple aquifers consisting principally of a tectonic assemblage of basement rocks and their Triassic sedimentary covers (Fig. 1). In general, the permeability of the basement aquifers is small, except for some circulation along isolated fracture zones and open joints. 
The Triassic sedimentary overburden is typically composed of quartzites, marbles, limestones, dolomites, and evaporites, of which in particular the carbonates and evaporites tend to constitute important potential aquifers as they are characterized by locally very high permeabilities related to abundant faults and fractures (Figs. 1 and 2). This fracture-dominated permeability may be locally further enhanced by the presence of features related to karstification processes (Bureau d'Etudes Géologiques S. A., unpublished data, 1987).

The Combioula thermal springs are related to Triassic rocks composed predominantly of quartzite, dolomite, limestone and gypsum (Fig. 1). For the period 1961-1990, the mean annual rainfall for this region is $652 \mathrm{~mm} / \mathrm{year}$, with generally more accentuated precipitation during the spring and autumn, and the mean annual temperature is $6.4^{\circ} \mathrm{C}$. The hydographic system is generally dendritic and the two rivers of the main valleys La Borgne and $\mathrm{La}$
Dixence flow to the Rhône River perpendicularly to the structures of the Penninic structural grain.

The surface expression of the Combioula hydrothermal system is composed of some 80 thermal, sub-thermal and cold springs emerging primarily along the riverbanks of the La Borgne over a distance of about $100 \mathrm{~m}$. These springs with their generally highly mineralized waters were supposedly discovered around $\mathrm{AD} 1530$ and were subsequently exploited for salt and therapeutic bathing. In 1986, three boreholes (C2, C3, and C3bis) were drilled near the springs and close to the river La Borgne with the objective to set up a thermal spa. These boreholes reach depths of $274 \mathrm{~m}$ for $\mathrm{C} 2,438 \mathrm{~m}$ for $\mathrm{C} 3$, and $412 \mathrm{~m}$ for C3bis. A commercial use of the thus accessed thermal water has not, however, materialized to date. A primary reason for this is that only borehole $\mathrm{C} 2$ remained open, whereas the two other wells were rapidly plugged by the precipitation of gypsum. Consequently, this study focuses

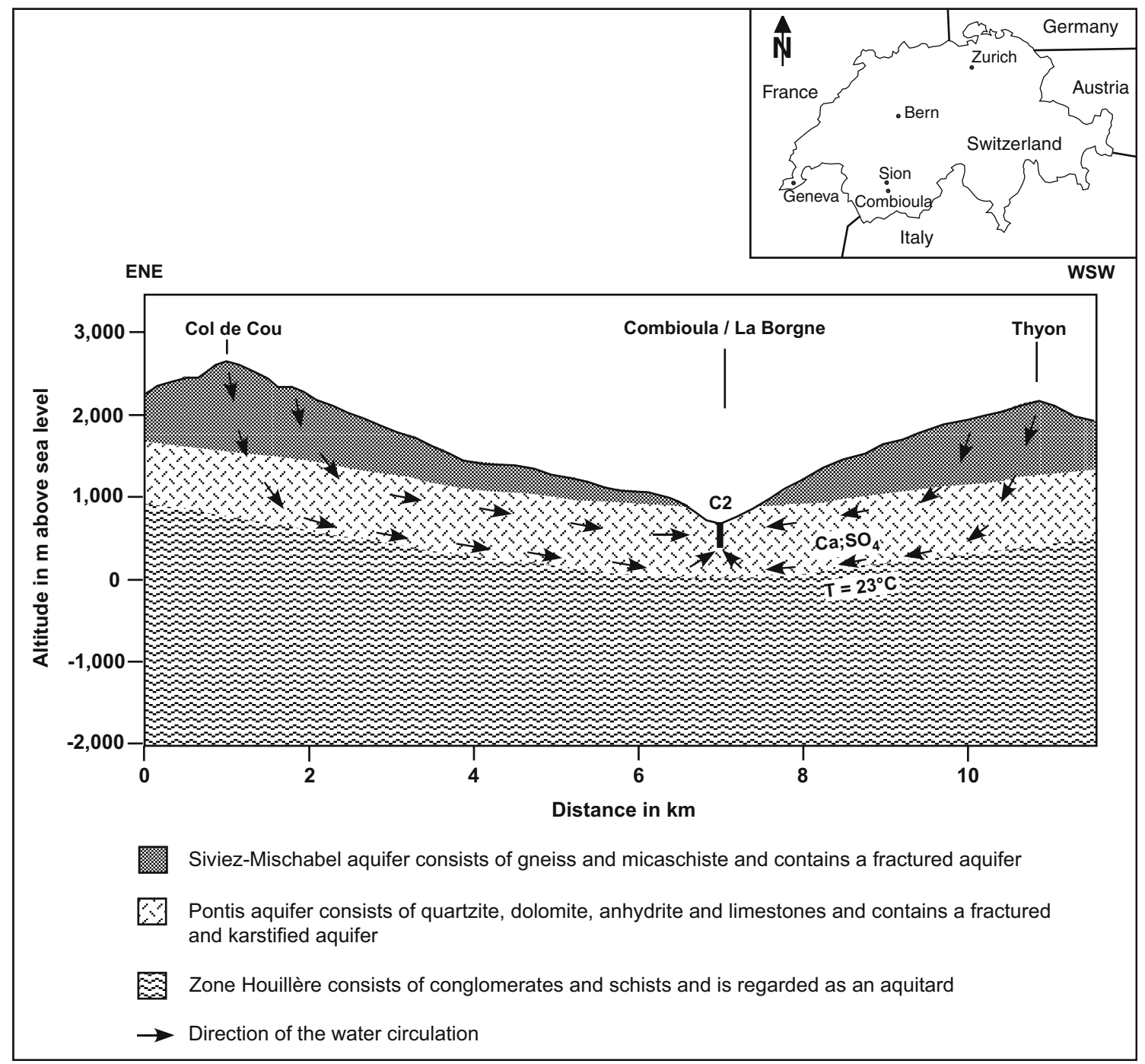

Fig. 1 Conceptual model of the Combioula hydrothermal system. The borehole $C 2$ considered in this study crosses the fractured and karstified Pontis aquifer. The actual reservoir of the Combioula hydrothermal system is hosted by the Pontis aquifer. The basement of the underlying Zone Houillère is largely impermeable and hence can be regarded as a regional aquitard for deep-water circulation (after Ladner, University of Neuchâtel, unpublished data, 2005) 
on borehole $\mathrm{C} 2$, which first crosses a highly permeably alluvial deposit and then from $42 \mathrm{~m}$ down to $274 \mathrm{~m}$ depth a carbonate sequence with intercalations of gypsum corresponding to the so-called Pontis aquifer (Figs. 1 and 2).

\section{Hydrochemistry}

In the framework of several studies of regional thermal waters, the boreholes, springs and rivers were sampled at Combioula (Vuataz 1983; Ladner, University of Neuchâtel, unpublished data, 2005). The temperature of the deep reservoir was estimated by hydrochemical methods to be around $40^{\circ} \mathrm{C}$. The tritium concentration indicates that most of the water in borehole $\mathrm{C} 2$ is relatively young and infiltrated after 1952 so that the recharge can be assumed to have occurred under present climatic conditions. The oxygen and deuterium isotopic values indicate a mean altitude of infiltration zones about 2,500-3,000 m above sea level. This infiltration zone is supposed to be the Vallon de Réchy, a small valley situated to the east of Val d'Hérens.

Recent sampling by means of pumping tests and corresponding analyses of the water of borehole $\mathrm{C} 2$ yields an average $\mathrm{pH}$ of 6.8 and an average fluid electrical conductivity of $2,990 \mu \mathrm{S} \mathrm{cm} \mathrm{c}^{-1}$ (Ladner, University of Neuchâtel, unpublished data, 2005). The dominant ions are calcium and sulphate and the chemical type of the fluid is $\mathrm{Ca}>\mathrm{Mg} ; \mathrm{SO}_{4}$ (Table 1). The observed water chemistry is thought to principally originate from dissolution within the local carbonate and evaporite series consisting predominantly of dolomitic limestone containing gypsum and anhydrite layers. In particular, the dissolution of gypsum and anhydrite and to a lesser extent of dolomite and dolomitic limestone is considered to be largely responsible for the overall mineralization of the Combioula thermal springs.

The calculation of the saturation index of the sampled water in well $\mathrm{C} 2$ has shown that the water is (1) oversaturated for quartz, (2) quasi-saturated with respect to gypsum and (3) under-saturated for dolomite and calcite (Fig. 3). This in turn indicates that primarily hydrated forms of silica and, to a more limited extent, gypsum can be expected to precipitate along the borehole walls and inside the hydraulically active fractures.

\section{Electrokinetic self-potential signals}

When groundwater flows through a saturated porous medium, electric and hydraulic processes are coupled as there is always an excess of electrical charges in the vicinity of the water/mineral interface (Pride 1994; Revil et al. 2003). This phenomenon is generally referred to as the diffuse double layer and the associated drag of this

Fig. 2 Lithology of the borehole C2 (courtesy of Bureau d'Etudes Géologiques S.A., unpublished data, 1987)

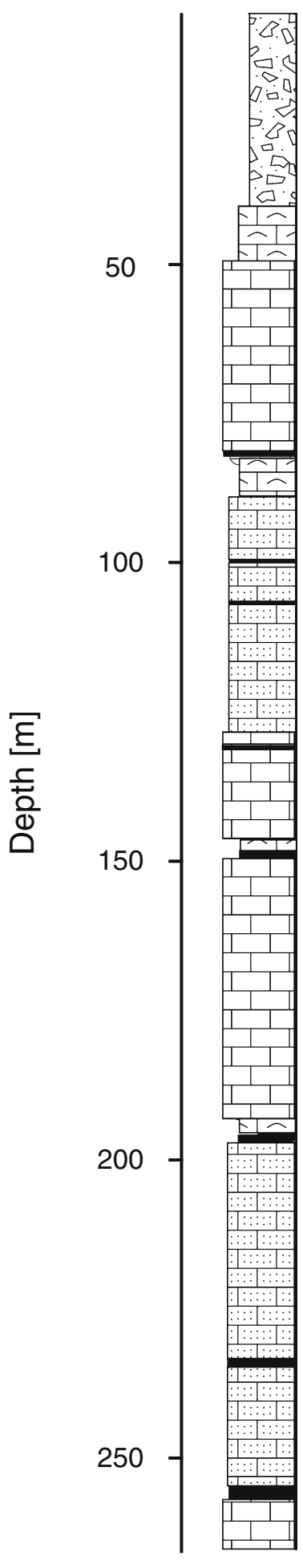

\section{Alluvium \\ Limestone \\ Dolomitic limestone \\ Gypsum /Anhydrite}

\section{Fracture}


Table 1 Average hydrochemistry for $\mathrm{C} 2$ borehole water, which can be classified as being of type $\mathrm{Ca}>\mathrm{Mg} ; \mathrm{SO}_{4}$

\begin{tabular}{|c|c|c|c|c|c|c|c|c|c|c|}
\hline Sample date & $\mathrm{pH}$ & Temperature ${ }^{\circ} \mathrm{C}$ & $\begin{array}{l}\text { Electrical } \\
\text { Conductivity } \\
\mu \mathrm{S} \mathrm{cm}{ }^{-1}\end{array}$ & $\begin{array}{l}\mathrm{K} \\
\mathrm{mg} \mathrm{L}\end{array}$ & $\begin{array}{l}\mathrm{Mg}^{-1} \\
\mathrm{mg} \mathrm{L}^{-1}\end{array}$ & $\begin{array}{l}\mathrm{Ca} \\
\mathrm{mg} \mathrm{L}^{-1}\end{array}$ & $\begin{array}{l}\mathrm{Na} \\
\mathrm{mg} \mathrm{L}^{-1}\end{array}$ & $\begin{array}{l}\mathrm{Cl} \\
\mathrm{mg} \mathrm{L}^{-1}\end{array}$ & $\begin{array}{l}\mathrm{SO}_{4} \\
\mathrm{mg} \mathrm{L}^{-1}\end{array}$ & $\begin{array}{l}\mathrm{HCO}_{3} \\
\mathrm{mg} \mathrm{L}^{-1}\end{array}$ \\
\hline $26 / 08 / 2005$ & 6.8 & 22.5 & 2,990 & 8.5 & 94.8 & 537.1 & 87.7 & 76.0 & $1,536.8$ & 219.0 \\
\hline $30 / 08 / 2005$ & 6.75 & 23.1 & 2,990 & 7.4 & 89.1 & 552.5 & 89.1 & 77.0 & $1,550.3$ & 211.1 \\
\hline
\end{tabular}

excess of charge by the flow of the groundwater is responsible for a net source of electrical current that polarizes the porous continuum (Ishido and Mizutani 1981; Revil et al. 1999). The flow of water through a porous medium thus inherently generates an electrical field and the associated "spontaneous" difference in voltage, or electrical potential, is generally referred to as the electrokinetic or streaming potential (e.g., Sill 1983; Fournier 1989; Birch 1993, 1998; Doussan et al. 2002; Suski et al. 2006). The electrokinetic self-potential represents one of several possible contributions to the total self-potential signal measurable inside a borehole. Other contributions might arise from: (1) the presence of metal or metallic minerals (redox potential), (2) a chemical difference between the liquid used in drilling and the fluid enclosed in the formation drilled (membrane potential), and (3) the filtrate and the formation fluid at the boundary of the invaded zone, a phenomenon also known as liquid junction potential (e.g., Chapellier 1992). In this case study, the two dominant sources of self-potentials are expected to be the redox potential along the first $50 \mathrm{~m}$ due to the presence of a metallic casing and the electrokinetic potential along the remaining open part of the borehole due to the presumed circulation of groundwater inside the fractures (Fig. 2).

Various applications of self-potential signals in general and electrokinetic self-potential signals in particular to assess and characterize geothermal resources (e.g., Anderson and Johnson 1973; Corwin and Hoover 1979), to determine the preferential path of groundwater flow (e.g., Jardani et al. 2006a, b), to determine hydraulic properties of the shallow subsurface (e.g. Rizzo et al. 2004), and to identify hydrofracturing (e.g. Byrdina et al. 2003) have been reported to date. Despite this remarkably broad range of applications, however, only very few systematic studies regarding the relationship between electrokinetic self- potential signals and the hydraulic activity of fractures exist (Bogoslovsky and Ogilvy 1972, 1973; Wishart et al. 2006; Moore and Glaser 2007) and corresponding applications to borehole studies are in even shorter supply (Hunt and Worthington 2000; Ishido and Pritchett 2003).

In the classical formulation of the electrokinetic potential, electrical and hydraulic processes are coupled. At the scale of a representative elementary volume of the considered porous material, the total electrical current density $\mathbf{J}$ is the sum of a conductive current described by the Ohm's law $\mathbf{J}_{\mathbf{0}}$ and a net or driving electrokinetic source current density $\mathbf{J}_{\mathbf{S}}$, which is associated with the pore fluid pressure field $p$ (e.g., Sill 1983):

$\mathbf{J}=\mathbf{J}_{\mathbf{0}}+\mathbf{J}_{\mathbf{S}}=-\sigma \nabla \varphi+\sigma C \nabla p$

with

$C \equiv-L / \sigma$,

where $\varphi$ is the electrical potential in $\mathrm{V}, \sigma$ is the electrical conductivity of the porous medium in $\mathrm{S} \mathrm{m}^{-1}, C$ is the electrokinetic potential coupling coefficient in $\mathrm{V} \mathrm{Pa}^{-1}$, and $L$ is the coupling coefficient of the electrokinetic current in $\mathrm{m}^{2} \mathrm{~V}^{-1} \mathrm{~s}^{-1}$. The electrokinetic current density $\mathbf{J}_{\mathbf{S}}=$ $\sigma C \nabla p$ acts as a source term for electromagnetic disturbances in the Maxwell equations. Combining the constitutive Eq. (1) and the continuity equation $\nabla \cdot \mathbf{J}=0$ stating that the current density is conservative under the static or quasi-static conditions, one obtains a Poissontype equation for the electrical potential:

$\nabla(\sigma \nabla \varphi)=\nabla(L \nabla p)=\Im$

where $\mathfrak{I}$ represents the volumetric density of the current source in $\mathrm{A} \mathrm{m}^{-3}$.
Fig. 3 Calculations of the saturation index as a function of the temperature for the water in borehole $\mathrm{C} 2$ with regard to anhydrite, calcite, dolomite, gypsum and quartz. The vertical red line represents the mean water temperature inside the borehole (after Ladner, University of Neuchâtel, unpublished data, 2005)

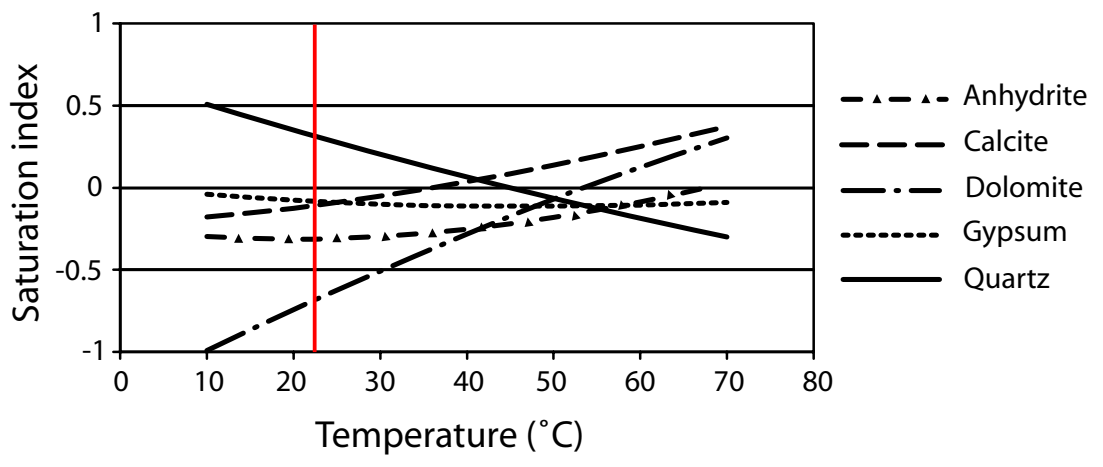


Equation 3 can be simplified by assuming steady-state equilibrium conditions as well as negligible surface conductivity along the mineral grains. These assumptions are generally valid for laminar capillary flow and in absence of significant amounts sheet-silicates such as clays or mica. As indicated by Eq. 3, the gradient of electrokinetic potential $\nabla \varphi$ is then directly related to the corresponding pressure gradient $\nabla p$ :

$\nabla \varphi=C \nabla p$

where $C$ is the electrokinetic potential coupling coefficient defined in Eq. 2. Equation 4 is the well-known HelmholtzSmoluchowski equation. In can be shown that for laminar capillary flow, $C$ is defined as (e.g., Overbeek 1952):

$C=\frac{\varepsilon_{f} \zeta}{\eta_{f} \sigma_{f}}$

where $\varepsilon_{f}$ is the dielectric permittivity of the fluid in $\mathrm{F} \mathrm{m}^{-1}$, $\sigma_{f}$ the fluid electrical conductivity in $\mathrm{S} \mathrm{m}^{-1}, \eta_{f}$ the fluid viscosity in $\mathrm{Pa} \mathrm{s}$, and $\zeta$ the so-called zeta potential of the double layer in V. Although the above expression for the electrokinetic coupling coefficient is strictly valid only for laminar capillary flow, there is increasing evidence to suggest that, for practical intents and purposes, it provides a good approximation for laminar groundwater flow regimes in general, including laminar flow in fractured media (e.g., Beamish and Peart 1998; Gorelik 2004; Moore and Glaser 2007).

Equation (5) illustrates that the form of the relation between the self-potential signal and the pressure variation will depend mainly on the zeta potential. Unfortunately, there are no core samples or cuttings available and hence it was not possible to directly measure the zeta potentials of various lithologies encountered along the borehole in the laboratory. The zeta potential is a key parameter in electrokinetic self-potential studies characterizing the fluid/mineral interface generated by the chemical interaction of the minerals and the fluid. This parameter is, essentially, the reflection of the distribution of surface charges along the fluid/mineral interface and thus of the diffuse double layer, which in turn depends on a number of parameters, like the fluid electrical conductivity or the $\mathrm{pH}$. Evidently, this tends to make self-potential measurements delicate to interpret, both quantitatively and qualitatively (e.g., Crespy et al. 2007). This is particularly true for carbonates for which the magnitude of the zeta potential is inherently variable and its sign can be both positive and negative (Vdovic 2001; Moulin and Roques 2003). Most importantly for the present study, the zeta potential of most carbonates tends to be close to zero for pH-values around 7 (Guichet et al. 2006). Conversely, the zeta potentials of both quartz and gypsum are clearly negative. For an ionic strength equal to $0.07 \mathrm{M}$, a fluid electrical conductivity equal to $0.3 \mathrm{~S} \mathrm{~m}^{-1}$, and $\mathrm{pH}$ equal to 6.8, Johnson (1999), found that zeta potential for quartz particles ranged between $-30 \mathrm{mV}$ and $-16 \mathrm{mV}$, whereas
Titiz-Sargut et al. (2007) reports a zeta potential equal to $12.5 \mathrm{mV}$ for gypsum particles.

Based on the hydrochemical evidence outlined above, one can therefore assume that the zeta potential along the considered borehole at the Combioula hydrothermal site is most likely to be negative and its absolute value to range between 10 and $30 \mathrm{mV}$. This then allows one to determine the sign of the pressure variation associated with the hydraulically active fractures based on the observed selfpotential anomalies as well as to obtain a first-order estimate of the pressure change along the fractures (Eqs. 4 and 5). The observed electrical potentials discussed in the following are measured with respect to a reference electrode, which in this case study corresponds to the steel cable along which the logging tool is suspended. As this reference electrode is also located inside the borehole, a positive self-potential anomaly is indicative of a drop in the water pressure and thus implies that water flows out of the borehole into the fracture, whereas a negative selfpotential anomaly corresponds to an increase in pressure and thus implies that water flows through the fracture into the borehole.

\section{Results}

Measurements of the self-potential, complemented by measurements of fluid electrical conductivity corrected for temperature and normalized to the standard temperature of $25^{\circ} \mathrm{C}$, fluid temperature, and the borehole diameter or caliper, were performed along borehole $\mathrm{C} 2$ at an increment of $5 \mathrm{~cm}$ (Fig. 4c through f) using Mount Sopris borehole logging equipment. At the time of the measurements, the water level was located at $6.2 \mathrm{~m}$ below surface and the temperature increased from $\sim 10^{\circ} \mathrm{C}$ at the surface to $\sim 24^{\circ} \mathrm{C}$ at the bottom of the well.

The temperature log and the corresponding temperature gradient log indicate two major changes, one at $\sim 40 \mathrm{~m}$ depth and another one at $\sim 100 \mathrm{~m}$ depth (Fig. 4e). The relatively small change in temperature at $\sim 40 \mathrm{~m}$ depth, more visible as a pronounced variation of its gradient, corresponds to the transition from the overlying alluvium to the underlying basement. The fluid electrical conductivity and its gradients also point to a major change in water chemistry near the base of the surficial alluvial aquifer at $\sim 40 \mathrm{~m}$ depth where the conductivity jumps from $0.11 \mathrm{~S} \mathrm{~m}^{-1}$ to $0.22 \mathrm{~S} \mathrm{~m}^{-1}$ and then gradually increases to $0.27 \mathrm{~S} \mathrm{~m}^{-1}$ at bottom of the borehole at $260 \mathrm{~m}$ depth (Fig. 4f). This indeed indicates that there are two separate aquifer systems, a surficial one alimented by local infiltration through the alluvium and a second deeper one in the underlying carbonates forming part of largescale, deep-reaching groundwater circulation system. Although the borehole casing down to $\sim 50 \mathrm{~m}$ depth should effectively isolate the deeper carbonate aquifer from the surficial alluvial aquifer, the temperature and fluid electrical conductivity logs both provide evidence to the contrary, which implies that the casing is likely to be permeable in the depth range between $\sim 35$ and $\sim 45 \mathrm{~m}$. 
The temperature log shows the most significant variation at $\sim 100 \mathrm{~m}$ depth, which essentially divides the thermal regime observed along the borehole into two regions: the region above $\sim 100 \mathrm{~m}$ depth, where the temperature increases rapidly from $\sim 10$ to $\sim 24^{\circ} \mathrm{C}$ and a gradient of $\sim 15^{\circ} \mathrm{C}$ per $100 \mathrm{~m}$, and the region below $\sim 100 \mathrm{~m}$ depth, where the temperature increases very slowly with a gradient of $\sim 1^{\circ} \mathrm{C}$ per $100 \mathrm{~m}$. This

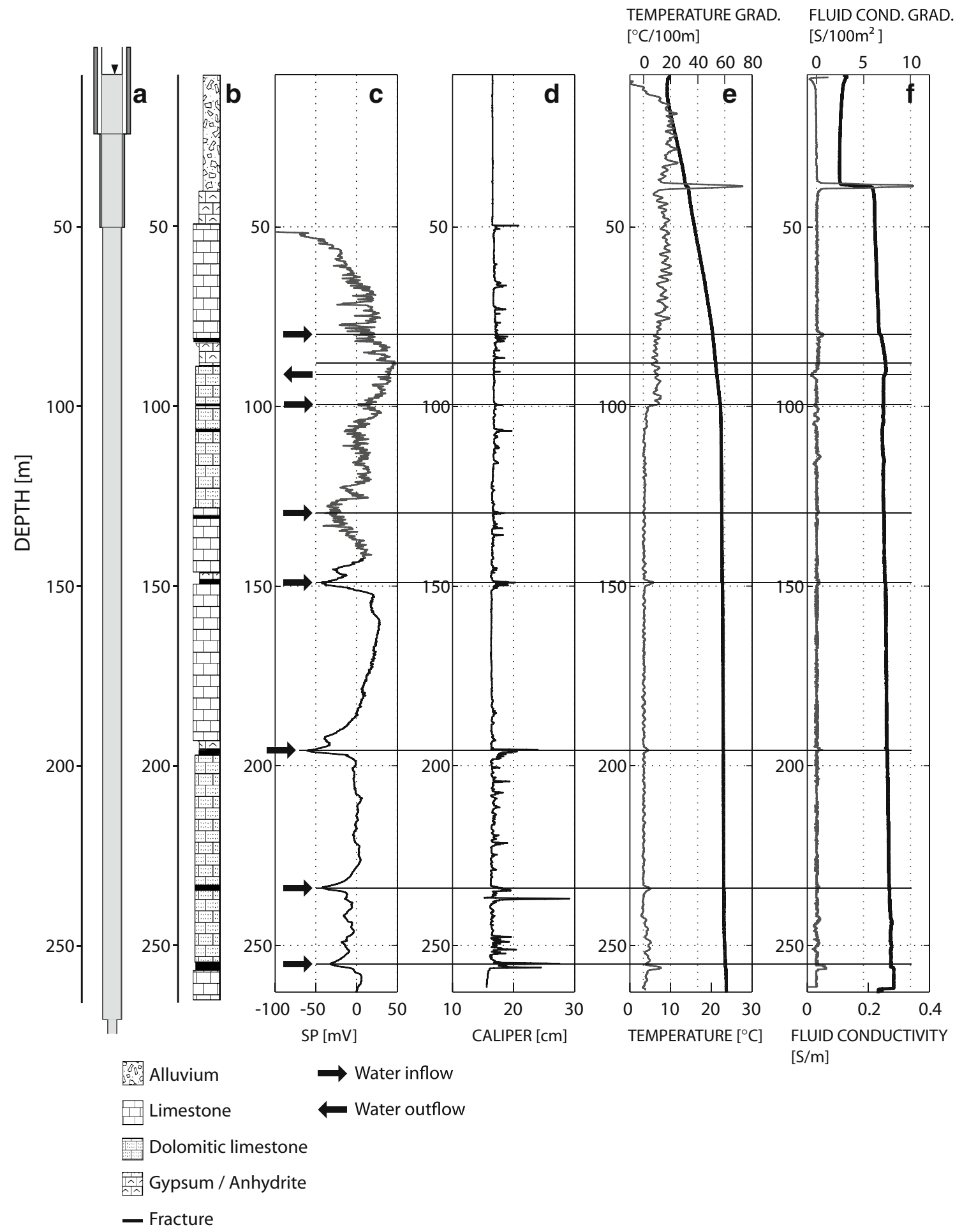

Fig. 4 Result of the logging inside borehole C2: a technical sketch of C2 showing cased parts and variations in diameter, b lithology (Bureau d'Etudes Géologiques S.A., unpublished data, 1987), c self-potential $\log (\mathrm{mV})$, d caliper $\log (\mathrm{cm})$, e water temperature $\left({ }^{\circ} \mathrm{C}\right)$, d and temperature gradient $\left({ }^{\circ} \mathrm{C} / 100 \mathrm{~m}\right) \operatorname{logs}$, and $\mathbf{f}$ fluid electrical conductivity $\left(\mathrm{S} \mathrm{m}^{-1}\right)$ and fluid electrical conductivity gradient $\left(\mathrm{S} / 100 \mathrm{~m}^{2}\right)$ logs. The horizontal lines indicate the major self-potential anomalies interpreted to be associated with hydraulically active fractures 
pronounced change in temperature at $\sim 100 \mathrm{~m}$ depth could be most easily reconciled with important inflows and/or outflows of water in the same depth range. This is turn would suggest that the first $\sim 100 \mathrm{~m}$ of water inside the borehole are likely to represent a mix between colder and more resistive meteoric water from the surficial alluvial aquifer and warmer and more conductive water from the deeper carbonate aquifer prevailing in the lower part of the borehole. Interestingly, the rather dramatic change in the thermal regime at $\sim 100 \mathrm{~m}$ does not find any reflection in the electrical conductivity of the water and its gradients, whereas the pronounced jump in the fluid electrical conductivity at the base of the surficial alluvial aquifer at $\sim 40 \mathrm{~m}$ is only associated with relatively weak change in temperature. At present, there is no conclusive explanation for this seemingly inconsistent stratification of the water column inside the borehole with regard to temperature and fluid electrical conductivity.

The self-potential measurements are depicted in Fig. 4c. The first $\sim 50 \mathrm{~m}$ of the self-potential log are not shown here because the strong redox potential associated with the metallic casing (Fig. 4a) perturbed the measurements too much. Therefore only the measurements made below the bottom of the metallic casing are discussed. Moreover, given that for the borehole logging system used in this study the reference electrode corresponds to the steel cable suspending the logging tool, self-potential measurements continue to be influenced by the steel casing for another $\sim 20 \mathrm{~m}$ below its base. A rough qualitative comparison between the self-potential and the borehole diameter or caliper logs (Fig. 4c and d) shows that the self-potential measurements correlate with some of the individual enlargements of the caliper. In the given geological context, caliper enlargements are likely to be indicative of laterally pervasive fractures or, alternatively, of lateral cavities of limited lateral extent. A comparison of the caliper and self-potential logs should thus allow one to distinguish hydraulically active fractures from cavities or hydraulically inactive fractures.

Two major self-potential domains of fundamentally differing signal character can be observed: the first domain ranges from the bottom of the casing to $\sim 140 \mathrm{~m}$ depth and is characterized by a strongly fluctuating and apparently rather noisy self-potential signal, whereas in the second domain, from $\sim 140$ to $\sim 260 \mathrm{~m}$ depth, the self-potential signal is much smoother (Fig. 4c). Interestingly, there does seem to be a remarkable correspondence in the overall nature of the self-potential and caliper logs in the two domains identified above. In the first domain from $\sim 50$ to $\sim 140 \mathrm{~m}$ depth, the seemingly noisy self-potential $\log$ is associated with a caliper $\log$ that is characterized by a large number and dense spacing of generally smaller enlargements of the borehole diameter. Conversely, in the second domain from $\sim 140$ to $\sim 260 \mathrm{~m}$ depth both the selfpotential and caliper logs shows relatively few, but generally rather prominent anomalies superimposed onto a smooth, largely noise-free background. This in turn suggests that the differing nature of the self-potential log in the upper and lower parts of the borehole could possibly be a direct reflection of fundamentally differing fracture and flow regimes in the two domains.

In the first domain ranging from $\sim 50$ to $\sim 140 \mathrm{~m}$ depth, five significant self-potential anomalies are present: one at $88.05 \mathrm{~m}$, a second one at $99.75 \mathrm{~m}$ and a third one at $127.85 \mathrm{~m}$ (Fig. 4c). Two additional, somewhat less obvious, anomalies are present at $\sim 80$ and $91 \mathrm{~m}$ depth. At $88.05 \mathrm{~m}$ depth the self-potential reaches a maximum that it is not correlated with any changes in the borehole diameter and/or fluid electrical conductivity and temperature. This variation could be correlated with the transition from gypsum/anhydrite to dolomitic limestone or it could be part of a broader and more complex signal related to an outflow of water around $91 \mathrm{~m}$ depth, which is possibly not associated with a single discrete fracture. The latter interpretation would be consistent with the corresponding change in the fluid electrical conductivity and its gradient. Similarly, the noisy minimum of the self-potential $\log$ at $\sim 80 \mathrm{~m}$ depth, which coincides with a fracture in the litholog, a caliper enlargement and a change in the fluid electrical conductivity, is likely to correspond to another fluid inflow. The local self-potential minimum at $99.75 \mathrm{~m}$ depth is associated with a single caliper deviation and coincides with the boundary between the upper and lower thermal regimes in the water column of the borehole, discussed above, but has no clear correspondence in the electrical conductivity log. This anomaly is therefore likely to correspond to a pronounced inflow of warm water. The self-potential anomaly at $127.85 \mathrm{~m}$ is negative indicating that water is flowing into borehole and associated with a corresponding deviation of the borehole diameter. Interestingly, this fracture has no clear signature in the temperature and fluid electrical conductivity measurements, which suggests that the water entering the borehole must have the same temperature and electrical conductivity as the water in the borehole. In the first domain not all caliper enlargements and/or fractures depicted in the litholog could be related to the self-potential data, which is likely to be largely due to their inherently noisy nature in this depth range.

The second domain from $\sim 140$ to $\sim 270 \mathrm{~m}$ depth shows four significant self-potential anomalies at 148.95, 195.85, 234.0 and $255.3 \mathrm{~m}$ depth, all of which are negative indicating that there are inflows of water from the surrounding formation into the borehole. These selfpotential minima are indeed generally well correlated with deviations in the borehole diameter as well as, albeit very small, variations of the temperature and/or fluid electrical conductivity gradients. The latter seems to indicate that the water column in the lower part of the borehole, below $\sim 100 \mathrm{~m}$ depth, is very close to a thermal and hydrochemical equilibrium. At $255.3 \mathrm{~m}$ depth, the self-potential signal is associated with two closely spaced, prominent borehole diameter enlargements. As these two prominent caliper deviations occur within $\sim 1 \mathrm{~m}$ of each other, it is difficult to assess whether the associated self-potential anomaly represents the integration of two distinct water inflows thus illustrating the inherently limited vertical resolution of self-potential logs or whether only one of the 
caliper enlargements is associated with a hydraulically active fracture. As the fluid temperature and the fluid electrical conductivity show only one discrete variation in this depth range, the latter hypothesis does, however, seem to be more probable. Interestingly, the largest caliper deviation at $236.95 \mathrm{~m}$ is not associated with a maximum or minimum in the self-potential signal and hence most likely does not correspond to a hydraulically active fracture. When the borehole was drilled in 1986, a significant water loss was observed at this depth (Bureau d'Etudes Géologiques S.A., unpublished data, 1987). One can therefore suppose that at the depth of $236.95 \mathrm{~m}$, the drill bit crossed at a large empty cavity, probably of karstic nature and origin, which filled up in the process and since then has remained hydraulically passive. Between the anomalies related to hydraulically active fractures, the self-potential signal is smooth and more or less stable around $0 \mathrm{mV}$ except for a positive long-wavelength anomaly between 160 and $190 \mathrm{~m}$ depth. This could, for example, be indicative of a redox potential due to the presence of trace mineralizations of pyrite or hematite, which tend to be relatively common in the given geological context. The overall groundwater flow pattern inferred from the self-potential measurements outlined above is entirely with today's, albeit still rather patchy, knowledge of the regional hydrogeology (Vuataz, 1983; Ladner, University of Neuchâtel, unpublished data, 2005).

Finally, using the simplified relationship between the self-potential signals and the pressure variation (Eqs. 4 and 5), it is possible to obtain a rough, first-order estimate of the range of pressure changes associated with the active fractures. Based on the observed self-potential signals and using the two end-member estimates for the zeta potential of -30 and $-12.5 \mathrm{mV}$, pressure variations were obtained ranging between -0.85 and $-1.15 \mathrm{MPa}$ and between -2.05 and $-2.75 \mathrm{MPa}$, respectively. Although these estimates must at present be regarded as inherently speculative in nature until verified by proven traditional hydrological techniques such as packer tests and flowmeter measurements, they do potentially provide critical constraints for the quantitative characterization of fractured aquifers.

\section{Conclusion}

A combined geophysical and hydrochemical study was performed along a 260-m-deep borehole penetrating a fractured carbonate aquifer at the Combioula hydrothermal site in the southwestern Swiss Alps. Self-potential signals and hydrochemical analyses were complemented by temperature, fluid electrical conductivity and borehole diameter or caliper logs in order to explore the sensitivity of this method for the detection and characterization of the groundwater flow inside the fractures. Overall, the selfpotential signals were found to show a good correlation with the caliper, water temperature and fluid electrical conductivity logs, which made it possible to link the selfpotential signals to the fracture network and to distinguish the hydraulically active fractures from inactive ones. A particularly interesting outcome of this study is that the evidence provided by the hydrochemical analyses proved to be critical for a unique determination of the sign of the zeta potential as well as an approximate estimation of its magnitude. This in turn proved to be essential for a correct interpretation of the direction of the fluid flow inside the fractures as well as for tentative first-order estimates of the pressure changes associated with hydraulically active fractures. The results of this study therefore suggest that, in conjunction with hydrochemical constraints, the selfpotential borehole logging method is a potentially useful tool for the detection and characterization of hydraulically active fractures as well as for the overall understanding of complex fluid flow patterns in fractured aquifers. Future research should therefore aim at testing and exploring the quantitative validity of the predictions inferred from the self-potential measurements and developing comprehensive numerical models for the self-potential response for laminar flow in fractured media. Combined with traditional hydrological techniques such as flowmeter measurements and/or pumping and packer tests, the information provided by self-potential logs could therefore prove to be an effective means for developing quantitative hydraulic models, which are critically needed to allow for a sustainable use of the inherently complex but increasingly important class of fractured aquifers and geothermal reservoirs.

Acknowledgements This work was partially supported by grants from the Swiss National Science Foundation. We thank the local authorities for allowing us access to their boreholes, B. Dafflon for help with the acquisition and processing of some of the data, P. Gex and A. Revil for interesting discussions and helpful suggestions. Constructive and insightful comments by the referees and editors greatly improved the quality of this manuscript.

\section{References}

Anderson L, Johnson G (1973) Application of self-potential method in search for geothermal-energy. Geophysics 38:1190-1190

Beamish D, Peart RJ (1998) Electrokinetic geophysics: a review. Terra Nova 10:48-55

Birch FS (1993) Testing Fournier's method for finding water table from self-potential. Ground Water 31:50-56

Birch FS (1998) Imaging the water table by filtering self-potential profiles. Ground Water 36:779-782

Bogoslovsky VV, Ogilvy AA (1972) Streaming potential in fissured media. Geophys Prospect 20:109-117

Bogoslovsky VV, Ogilvy AA (1973) Deformation of natural electric fields near drainage structures. Geophys Prospect 2:716-723

Byrdina S, Friedel S, Wasserman J, Zlotnicki J (2003) Self-potential variations with ultra-long-period seismic signals at Merapi volcano. Geophys Res Lett 30:2156

Chapellier D (1992) S.P. LOG. In: Well logging in hydrogeology. Balkema, Rotterdam, The Netherlands

Corwin RF, Hoover DB (1979) Self-potential method in geothermal exploration. Geophysics 44:226-245

Crespy A, Bolève A, Revil A (2007) Influence of the Dukhin and Reynolds numbers on the apparent zeta potential of granular porous media. J Colloid Interface Sci 305:188-194

Doussan C, Jouniaux L, Thony JL (2002) Variations of selfpotential and unsaturated water flow with time in sandy loam and clay loam soils. J Hydrol 267:173-185 
Durand V, Deffontaines B, Leonardi V, Guerin R, Wyns R, de Marsily G, Bonjour JL (2006) A multidisciplinary approach to determine the structural geometry of hard-rock aquifers: application to the Plancoet migmatitic aquifer (NE Brittany W France). Bull Soc Geol Fr 177:227-236

Escher A (1988) Structure de la nappe du Grand Saint-Bernard entre le Val de Bagnes et les Mischabel [Structure of the Grand Saint Bernard nappe between the Val de Bagnes and Mischabel]. Rapp géol Serv Hydrol Géol nat Suisse 7, Berne, Switzerland, $26 \mathrm{pp}$

Forster C, Smith L (1988) Groundwater flow systems in mountainous terrain 2: controlling factors. Water Resour Res 24:10111023

Fournier C (1989) Spontaneous potentials and resistivity surveys applied to hydrogeology in a volcanic area: case history of the Chaîne des Puys (Puy-de-Dôme France). Geophys Prospect 37:647-668

Gorelik LV (2004) Investigation of dynamic streaming potential by dimensional analysis. J Colloid Interface Sci 274:695-700

Guichet X, Jouniaux L, Catel N (2006) Modification of streaming potential by precipitation of calcite in a sand-water system: laboratory measurements in the $\mathrm{pH}$ range from 4 to 12 . Geophys J Int 166:445-460

Hunt CW, Worthington MH (2000) Borehole electrokinetic responses in fracture dominated hydraulically conductive zones. Geophys Res Lett 27:1315-1318

Ishido T, Mizutani H (1981) Experimental and theoretical basis of electrokinetic phenomena in rock-water systems and its applications to geophysics. J Geophys Res 86:1763-1775

Ishido T, Pritchett JW (2003) Characterization of fractured reservoirs using continuous self-potential measurements. Proc 28th Stanford Workshop on Geothermal Reservoir Engineering, Standford, CA, 27-29 January 2003

Jardani A, Dupont JP, Revil A (2006a) Self-potential signals associated with preferential groundwater flow pathways in sinkholes. J Geophys Res 111, B09204. DOI 101029/2005JB004231

Jardani A, Revil A, Akoa F, Schmutz M, Florsch N, Dupont JP (2006b) Least squares inversion of self-potential (SP) data and application to the shallow flow of groundwater in sinkholes. Geophys Res Lett 33(190), L19306. DOI 101029/2006GL027458

Jeong CH (2001) Effect of land use and urbanization on hydrochemistry and contamination of groundwater from Taejon area Korea. J Hydrol 253:194-210

Johnson PR (1999) A comparison of streaming and microelectrophoresis methods for obtaining the zeta potential of granular porous media surfaces. J Colloid Interface Sci 209:264-267

Le Borgne T, Bour O, Paillet FL, Caudal JP (2006) Assessment of preferential flow path connectivity and hydraulic properties at single-borehole and cross-borehole scales in a fractured aquifer. J Hydrol 328:347-359

Lemieux JM, Therrien R, Kirkwood D (2006) Small scale study of groundwater flow in a fractured carbonate-rock aquifer at the StEustache quarry Quebec Canada. Hydrogeol J 14:603-612

Lopez D, Smith L (1995) Fluid flow in fault zones: analysis of the interplay of convective circulation and topographically driven groundwater flow. Water Resour Res 31:1489-1503

Mapani BS (2005) Groundwater and urbanisation risks and mitigation: he case for the city of Windhoek Namibia. Phys Chem Earth Parts A/B/C 30:706-711
Moore JR, Glaser SD (2007) Self-potential observations during hydraulic fracturing. J Geophys Res 112(B2). DOI 101029/ 2006JB004373

Moulin P, Roques H (2003) Zeta potential measurement of calcium carbonate. J Colloid Interface Sci 261:115-126

Ogilvy AA, Ayed MA, Bogoslovsky VA (1969) Geophysical studies of water leakages from reservoirs. Geophys Prospect $17: 37-62$

Overbeek JTG (1952) Electrochemistry of the double layer In: Kruyt HR (ed) Colloid science, vol 1: irreversible systems. Elsevier, Amsterdam, pp 115-193

Paillet F (2004) Borehole flowmeter applications in irregular and large-diameter boreholes. J Appl Geophys 55:39-59

Pride SR (1994) Governing equations for the coupled electromagnetics and acoustics of porous media. Phys Rev B 50:15678-15696

Revil A, Pezard PA, Glover P (1999) Streaming potential in porous media 1: theory of the zeta potential. J Geophys Res 104:20021-20031

Revil A, Naudet V, Nouzaret J, Pessel M (2003) Principles of electrography applied to self-potential electrokinetic sources and hydrogeological applications. Water Resour Res 39(5), 1114. DOI 101029/2001WR000916

Rizzo E, Suski B, Revil A, Straface S, Troisi S (2004) Self-potential signals associated with pumping tests experiments. J Geophys Res 109, B10203. DOI 101029/2004JB003049

Rozycki A, Ruiz Fonticiella JM, Cuadra A (2006) Detection and evaluation of horizontal fractures in earth dams using the selfpotential method. Eng Geol 82:145-153

Sartori M, Marthaler M (1994) Exemples de relations soclecouverture dans les nappes Penniques du Val d'Hérens [Examples of basement-cover relations in the Penninic nappes of Vald'Hérens]. Schweiz Mineral Petrogr Mitt Bd 74:503-511

Sharma SP, Baranwal VC (2005) Delineation of groundwater-bearing fracture zones in a hard rock area integrating very low frequency electromagnetic and resistivity data. J Appl Geophys 57:155-166

Sill WR (1983) Self potential modeling from primary flows. Geophysics 48:76-86

Steck A, Epard JL, Escher A, Gouffon Y, Masson H (2001) Carte tectonique des Alpes de Suisse occidentale et des régions avoisinantes [Tectonic maps of western swiss Alps and adjacent regions]. Carte géologique spéciale no. 123, Office Fédéral Eaux Géologie, Berne, Switzerland

Suski B, Revil A, Titov K, Konosavsky P, Voltz M, Dagès C, Huttel O (2006) Monitoring of an infiltration experiment using the self-potential method. Water Resour Res 42, W08418. DOI 101029/2005WR004840

Titiz-Sargut S, Sayan P, Avci B (2007) Influence of citric acid on calcium sulfate dihydrate crystallization in aqueous media. Cryst Res Technol 42, 119. DOI 101002/crat200610783

Vdovic N (2001) Electrokinetic behaviour of calcite: the relationship with other calcite properties. Chem Geol 177:241-248

Vuataz FD (1983) Hydrology, geochemistry and geothermal aspects of the thermal waters from Switzerland and adjacent alpine regions. J Volcanol Geotherm Res 19:73-97

Wishart DN, Slater LD, Gates AE (2006) Self potential improves characterization of hydraulically-active fractures from azimuthal geoelectrical measurements. Geophys Res Lett 30,(17), L17314. DOI 101029/2006GL027092 